\title{
PLATINUM HYPERSENSITIVITY REACTIONS, A FOCUS ON DESENSITISATION
}

\author{
ANDREI HAVASI ${ }^{1 \#}$, CRISTINA CRISAN ${ }^{2}$, ANA TEODORA HEPUTIU-PATER ${ }^{4}$, OVIDIU- \\ VASILE BOCHIS $^{2}$, CALIN CAINAP $^{2,3 \#}$, OVIDIU CRISAN ${ }^{7 *}$, OVIDIU BALACESCU $^{2 \#}$, \\ LOREDANA BALACESCU ${ }^{2}$, SIMONA CAINAP ${ }^{5,6}$
}

\author{
${ }^{I}$ Department of Research, Development and Innovation, "Iuliu Hatieganu” University of Medicine and Pharmacy, Cluj- \\ Napoca, Romania \\ 2 "Prof. Dr. Ion Chiricuță”, Institute of Oncology, Cluj-Napoca 400015, Romania \\ ${ }^{3}$ Department of Oncology, "Iuliu Haţieganu” University of Medicine and Pharmacy, Cluj-Napoca, Romania \\ 4 "Dr. Gavril Curteanu” Municipal Clinical Hospital, Oradea, Romania \\ ${ }^{5}$ Department of Mother and Child "Iuliu Hatieganu" University of Medicine and Pharmacy, Cluj-Napoca, Romania \\ ${ }^{6}$ Department of Pediatrics, Emergency Pediatric Clinical Hospital, Cluj Napoca, Romania \\ ${ }^{7}$ Faculty of Pharmacy, "Iuliu Hatieganu” University of Medicine and Pharmacy, Cluj-Napoca, Romania
}

*corresponding author: ocrisan@umfcluj.ro

${ }^{\#}$ Authors with equal contribution.

\begin{abstract}
Platinum-based chemotherapy is the standard of care in a wide array of cancers. All chemotherapy, including platinum derivates, can cause hypersensitivity reactions which greatly limit their use due to the risk of anaphylaxis, forcing oncologists to use alternative chemotherapy, sometimes with a lower efficacy. The exact pathogenesis of platinum hypersensitivity reactions remains unknown, a type I mechanism is most frequently involved; however, type II, III, IV, or mixed mechanisms have also been described. Patients with atopy, a long platinum-free interval, treatment in palliative setting and higher cumulative dose are at risk of hypersensitivity. For these patients, desensitization protocols are available to treat allergic reactions to various agents, including platinum chemotherapy. Desensitization promotes antigen tolerance and allows the safe and efficient administration of the agent responsible for the hypersensitivity reaction. This review aims at providing insight into the current knowledge of platinum hypersensitivity with focus on available desensitization protocols.
\end{abstract}

\section{Rezumat}

Chimioterapia pe bază de platină este piatra de temelie în tratamentul unei game variate de cancer. Toate chimioterapicele, inclusiv derivații de platină, pot provoca reacții de hipersensibilitate care limitează mult utilizarea lor datorită riscului de șoc anafilactic, obligându-i pe oncologi să utilizeze protocoale alternative de tratament, uneori cu o eficacitate mai redusă. Patogeneza exactă a reacțiilor de hipersensibilitate la platină rămâne necunoscută, cel mai frecvent este implicat un mecanism de tip I; cu toate acestea, au fost descrise și mecanisme de tip II, III, IV sau mixte. Pacienții cu atopie, interval liber de platina prelungit, tratament cu intenție paliativă și doză cumulată de platină mai mare prezintă un risc crescut de hipersensibilitate. Pentru acești pacienți, sunt disponibile protocoale de desensibilizare care permit combaterea reacțiilor alergice la diferiți agenți, inclusiv chimioterapicele pe bază de platină. Desensibilizarea promovează toleranța la antigen și permite administrarea sigură și eficientă a agentului responsabil de reacția de hipersensibilitate. Acest review își propune să ofere o trecere în revistă a datelor actuale cu privire la hipersensibilitatea la platină, cu accent pe protocoalele de desensibilizare disponibile.

Keywords: platinum hypersensitivity, desensitization, allergic reaction

\section{Introduction}

Cytotoxic chemotherapy may cause a wide range of adverse events that vary from gastrointestinal symptoms, cardiovascular toxicity, skin toxicity, cytopenia to severe hypersensitivity reactions (HSR) and anaphylaxis. Hypersensitivity reactions are serious, unexpected treatment complications that have been described for almost all chemotherapeutic agents and significantly limit their use. The clinical manifestations of HSR can range from mild symptoms as pruritus, urticaria, flushing to severe dyspnoea, hypotension, tachycardia and even death. Hypersensitivity reactions are classified as type I immediate immunoglobulin E (Ig E) mediated, type II antibody-mediated, type III immune complexmediated and type IV delayed or T-cell mediated HSR [76]. Chemotherapy-induced hypersensitivity reactions are complex and not completely understood. Even though most reactions are consistent with type I, Ig E - mediated reactions, some drugs may induce mixed hypersensitivity reactions with two or more involved mechanisms [13]. Platinum-based chemotherapy is the backbone of systemic therapy in a wide range of cancers, including, but not limited to 
gynaecologic [48, 49, 54], gastrointestinal [10, 12] and lung cancer $[3,50]$ for both adult and paediatric [67] patients. They represent a standard of care both in the first-line setting, but also for recurrent disease. Although they are efficient, generally well-tolerated chemo-therapeutic agents with manageable side-effects, their use is frequently restricted because of hypersensitivity reactions.

\section{Incidence\& risk factors}

Hypersensitivity reactions induced by chemotherapy are an important subgroup of drug-related adverse events that are unpredictable and may display various clinical symptoms, in some cases leading to anaphylaxis, cardiovascular collapse and death. An epidemiological analysis of fatal anaphylaxis in the United States from 1999 - 2010, placed anticancer therapy as the third leading cause of fatal drug-related anaphylactic reactions [27]. Cisplatin HSR frequency varies from 5 - 20\% [16] and increases with the number of administrations, as well as with the association of concurrent radiotherapy [10,33]. However, the number of cisplatin cycles is generally limited to $4-6$ administrations due to other limiting toxicities, and therefore cisplatin-induced HSR occurs less often. Carboplatin is a second-generation platinum derivate, and similar to cisplatin, the risk of HSR greatly varies with the number of administered cycles. Allergic reactions rarely appear during the first cycle, and they occur in $<1 \%$ for less than five administrations [71]. Nevertheless, for patients receiving seven or more administrations, the risk increases greatly to over $27 \%$ [45]. Furthermore, the existence of a platinumfree interval greater than six months and the administration of platinum compounds in the second or third-line setting raises the risk of allergic reactions up to $44 \%$ [53]. The cumulative carboplatin dose is linked to the risk of HSR; higher lifetime doses were associated with higher risk [55].

For oxaliplatin, an allergic reaction occurs in around $12 \%$ of cases. Most HSR are mild to moderate, with $1 \%$ of the patients presenting with severe, life-threatening reactions. Similar to carboplatin related HSR, oxaliplatin allergic reactions are more frequent in the second line and the palliative setting [4]. Patients treated in the first line with other compounds, particularly irinotecan had a higher risk or HSR compared to those treated in the first-line setting [70]. The number of administrations prior to the allergic reaction episode varies, but is similar to other platinum compounds ranging from 7 - 9 cycles. The time interval from starting the infusion to the onset of the hypersensitivity reaction varies from $10 \mathrm{~min}$ to 4 hours, with severe reactions occurring more frequently in the first $10 \mathrm{~min}[32,62]$.

A pre-existing allergic background is associated with a higher frequency of HSR. Patients presenting chemotherapy-induced allergic reactions have an increased incidence of atopy compared to the general population, of $44 \%$ [39, 46]. Although better outlined for the paediatric population, the administration schedule is another important factor, weekly administrations being linked to higher risk [81]. Moon et al. showed that the presence of breast cancer (BRCA) gene 1 and 2 mutations increase the risk for HSR by $43 \%$ [52]. Also, the cytotoxic chemotherapy agent administered with the platinum compound influences the risk of HSR. Data from the CIG CALYPSO trial showed that the association of carboplatin with paclitaxel is linked to a higher incidence of allergic reactions compared to liposomal doxorubicin [28]. A history of an allergic reaction to a specific platinum compound is linked to a greater risk of HSR to different platinum treatments, as switching platinum salts was not yet proved to be an efficient alternative [9].

Many of the oncological patients uses "supplements", which are considered harmless due to their natural origin. In fact, some of them could enhance the effect of chemotherapy (for cisplatin for example), but in the most of the cases it could increase the risk of an allergic reaction [69].

\section{Mechanism}

The exact pathogenesis of platinum induced hypersensitivity reaction remains mostly unknown. However, it is generally regarded to be primarily an Ig E - mediated process. Type I, Ig E-mediated hypersensitivity reactions, require a prior sensitization period. Ig $\mathrm{E}$ bind to mast cells and basophils, leading to the release of various cytokines such as histamine, leukotrienes and prostaglandins [58] which leads to the early onset of symptoms such as pruritus, chest pain, rash, and in some rare cases severe anaphylactic reactions. Type II allergic reactions have been reported for oxaliplatin with the production of anti-platelets and anti-erythrocytes directed antibodies, leading to immune thrombocytopenia and haemolytic anaemia [21, 43, 62]. Additionally, type III HSR, leading to joint pain, proteinuria or chronic urticaria have been described for oxaliplatin [44].

Recent data suggest the possibility of type IV, T cell-mediated hypersensitivity reactions to platinum compounds. The activated $\mathrm{T}$ helper cells cause a delayed inflammatory response, that may become clinically evident even days after the initial administration. Carboplatin and cisplatin are more frequently associated with delayed reactions, and most patients present with mild cutaneous manifestations such as maculopapular rash or eczema; however these patients are at risk of developing life-threatening complications such as Stevens-Johnson syndrome or toxic epidermal necrolysis $[13,57]$.

\section{Symptoms and management}

The clinical presentation of platinum induced hypersensitivity reactions can vary both in terms of clinical 
manifestations and the time of symptoms onset in relation to the drug administration. Most patients present cutaneous manifestations such as pruritus, urticaria, flushing or angioedema [40]. Other clinical manifestations such as dyspnoea, bronchospasm, diarrhoea, nausea, fever, chills and cardiovascular manifestations that may include arrhythmias and blood pressure variations have also been described [51, 63]. Respiratory symptoms are second to cutaneous manifestations in frequency, while cardiovascular symptoms are less common, but more severe [9]. Symptoms are common for all platinum derivates. However, oxaliplatin may display atypical presentations, including dyspnoea and hypoxia in the absence of bronchospasm, chills, fever, abdominal, back or chest pain during infusion, haematuria, hematemesis, epistaxis disorientation and altered mental status [4]. Dysesthesia with laryngeal spasm is a neurotoxic effect of oxaliplatin, and it should be distinguished from an allergic reaction [38].

Clinicians and patients have to be aware of the possibility of allergic reactions. Patients need to be counselled about the risk of hypersensitivity reactions and taught to distinguish the signs and symptoms and report them to the treating physician. An initial risk assessment must be carried out at treatment initiation and during the treatment. Patients at risk for platinum HSR should be monitored by experienced healthcare professionals, able to recognize and manage potentially life-threatening allergic reactions.

There are various classification systems to grade hypersensitivity reactions; however, the National Cancer Institute Common Terminology Criteria for Adverse Events v 4.03 is more frequently used [11]. In the face of an allergic reaction, treatment involves early diagnosis and cessation of drug administration. A quick evaluation of the patient's airways, breathing, circulation and consciousness are mandatory. Venous access must be ensured. For patients with anaphylaxis, epinephrine must be administered without delay. Oxygen must be administered if needed. Patients with hypotension must be placed in the Trendelenburg position. Fluid resuscitation must be initiated with the rapid administration of 1 - 2 litres of normal saline. Atropine is indicated for the treatment of bradycardia. Antihistamines improve symptoms such as pruritus and angioedema, but have no life-saving effect. Vasopressors may be needed in cases where epinephrine and fluid resuscitation failed. Corticosteroids are efficient in preventing delayed reactions, but their therapeutic effects occur after a few hours and therefore are inefficient in the management of acute severe allergic reactions. Vital signs and recurrence symptoms must be monitored post-reaction, and a $24 \mathrm{~h}$ close observation is recommended $[22,66,80]$.

\section{Desensitisation}

History of platinum related hypersensitivity reactions is a challenging issue that treating physicians have to surpass. The main predicament is whether platinumbased chemotherapy should be discontinued or not. After a platinum-related HSR, physicians have five possible options: premedication, prolonged infusion time, changing the platinum derivate, desensitisation and permanently discontinuing platinum derivates. When selecting the best treatment plan, the severity of the allergic reaction is a crucial deciding element. Other cofounding factors are treatment setting, palliative or curative treatment, the possible clinical benefit of continuing the platinum compound and the availability of other viable treatment options.

For patients with mild to moderate reaction, rechallenge with additional premedication, corticosteroids, antihistamines, or changing the platinum compound is an option; however, with limited efficiency, as crossreactivity between platinum derivates has been described and more intensive premedication still carries a high risk of severe allergic reactions [4, 24, 82]. Some studies have shown that prolonged infusion time might be an efficient option for some patients allowing treatment continuation and reducing further allergic reactions $[35,60,66]$. O'Cearbhaill et al. validated a prolonged 3-hour infusion protocol for carboplatin, compared to the standard 30 min infusion, coupled with rigorous premedication, which led to an $18 \%$ reduction of hypersensitivity reactions [56].

Recurrent reactions despite premedication or longer infusion time and serious initial allergic reactions oblige the use of desensitization protocols. First described for penicillin [72], desensitization is used in a wide array of clinical scenarios. Desensitization is the process by which the immune response is altered, in order to induce temporary tolerance to the targeted drug. During desensitization, the administration of subthreshold, incremental, antigen doses promotes the transduction of predominantly inhibitor signals, by abolishing intracellular calcium influx, which leads to increasing unresponsiveness to specific antigens [68]. Numerous desensitization protocols have been successfully used for various chemotherapy agents, including platinum derivates, allowing for treatment continuation. Most desensitisations use standardized multi-step administration protocols that allow the administration of the full therapeutic dose, usually in a short time interval of $4-12$ hours [57]. Table I encompasses the main desensitization protocols used for the treatment of platinum hypersensitivity reactions. 
FARMACIA, 2021, Vol. 69, 3

Table I

Published desensitization protocols for platinum hypersensitivity

\begin{tabular}{|c|c|c|c|c|c|c|c|c|}
\hline & Chemotherapy & Patients & Protocol & \begin{tabular}{|c|}
$\begin{array}{c}\text { Duration } \\
\text { (hours) }\end{array}$ \\
\end{tabular} & Setting & \begin{tabular}{|c|} 
Skin \\
testing
\end{tabular} & $\begin{array}{l}\text { BTR } \\
(\%)\end{array}$ & $\begin{array}{l}\text { Success } \\
\text { rate }(\%) \\
\end{array}$ \\
\hline $\begin{array}{c}\text { Castells et al. } \\
\text { [15] }\end{array}$ & $\begin{array}{l}\text { Carboplatin } \\
\text { Cisplatin } \\
\text { Oxaliplatin }\end{array}$ & 64 & $\begin{array}{l}12 \text { step, } 3 \text { dilutions } \\
\text { from } 1: 100-1: 1\end{array}$ & 5.8 & $\begin{array}{c}\text { ICU } 1^{\mathrm{st}} \text { administration; } \\
\text { Outpatient afterwards }\end{array}$ & Yes & 33 & 100 \\
\hline \multirow{2}{*}{ Kuo et al. [34] } & \multirow[t]{2}{*}{$\begin{array}{l}\text { Carboplatin } \\
\text { Oxaliplatin }\end{array}$} & \multirow[t]{2}{*}{10} & $\begin{array}{l}12 \text { step, } 3 \text { dilutions } \\
\text { from } 1: 100-1: 1\end{array}$ & 5.8 & \multirow[t]{2}{*}{ Outpatient } & \multirow[t]{2}{*}{ Yes } & \multirow[t]{2}{*}{16} & \multirow[t]{2}{*}{70} \\
\hline & & & $\begin{array}{c}5 \text { step dilutions from } \\
1: 10000-9: 10\end{array}$ & $2-5$ & & & & \\
\hline Abe et al. [1] & Cisplatin & 3 & $\begin{array}{c}6 \text { step dilutions from } \\
1: 1000-1: 1\end{array}$ & 12 & N/A & No & 33 & 66 \\
\hline $\begin{array}{c}\text { Altwerger } \text { et al. } \\
\text { [2] }\end{array}$ & Carboplatin & 129 & $\begin{array}{c}4 \text { steps dilutions from } \\
1: 1000-1: 1\end{array}$ & 3.5 & \begin{tabular}{|c|} 
Inpatient non-ICU \\
ICU $1^{\text {st }}$ administration: \\
1 patient
\end{tabular} & Yes & 27.1 & 87.6 \\
\hline Brault et al. [5] & $\begin{array}{c}\text { Carboplatin } \\
\text { Oxaliplatin } \\
\text { Cisplatin } \\
\end{array}$ & 30 & $\begin{array}{l}12 \text { steps dilutions } \\
\text { from } 1: 100 \text { to } 1: 1\end{array}$ & 3 & N/A & Yes & 36.6 & 86.6 \\
\hline \multirow{2}{*}{$\begin{array}{l}\text { Hesterberg et al. } \\
\text { [26] }\end{array}$} & \multirow[t]{2}{*}{ Carboplatin } & \multirow[t]{2}{*}{30} & $\begin{array}{l}8 \text { step, } 2 \text { dilutions } \\
\text { from } 1: 10 \text { to } 1: 1\end{array}$ & 6.35 & \multirow[t]{2}{*}{ Inpatient non-ICU } & \multirow[t]{2}{*}{ Yes } & \multirow[t]{2}{*}{17.9} & \multirow[t]{2}{*}{99} \\
\hline & & & $\begin{array}{c}10 \text { step dilutions from } \\
1: 100 \text { to } 1: 1\end{array}$ & 11.05 & & & & \\
\hline Wang et al. [79] & $\begin{array}{l}\text { Carboplatin } \\
\text { Oxaliplatin }\end{array}$ & 109 & $\begin{array}{l}12 \text { step, } 3 \text { dilutions } \\
\text { from } 1: 100-1: 1 \\
8 \text { step } 1: 10 \text { to } 1: 1\end{array}$ & $\begin{array}{l}5.8 \\
6.35\end{array}$ & Inpatient non-ICU & Yes & N/A & N/A \\
\hline \begin{tabular}{|c|} 
Bruchim et al. \\
[7]
\end{tabular} & Carboplatin & 49 & $\begin{array}{c}3 \text { step dilutions from } \\
1: 1000 \text { to } 1: 1\end{array}$ & $6 / 15.5$ & N/A & Yes & 20.4 & 89.7 \\
\hline Caiado et al. [8] & $\begin{array}{c}\text { Carboplatin } \\
\text { Oxaliplatin } \\
\text { Cisplatin } \\
\end{array}$ & 136 & $\begin{array}{l}12 \text { step: } 3 \text { dilutions } \\
\text { from } 1: 100-1: 1\end{array}$ & 6 & Outpatient & Yes & 16.3 & $93 \%$ \\
\hline $\begin{array}{c}\text { Castells et al. } \\
\text { [13] }\end{array}$ & Carboplatin & 31 & $\begin{array}{l}12 \text { step, } 3 \text { dilutions } \\
\text { from } 1: 100-1: 1\end{array}$ & 5.8 & $\begin{array}{c}\text { Inpatient non-ICU } \\
\text { ICU } 1^{\text {st }} \text { administration } \\
\end{array}$ & Yes & 35.4 & 100 \\
\hline Choi et al. [17] & Carboplatin & 8 & $\begin{array}{l}24 \text { steps, } 4 \text { dilutions } \\
\text { from } 1: 1000 \text { to } 1: 1\end{array}$ & 96 & Inpatient non-ICU & Yes & 0 & 100 \\
\hline $\begin{array}{c}\text { Chung et al. } \\
\text { [18] }\end{array}$ & $\begin{array}{l}\text { Carboplatin } \\
\text { Cisplatin } \\
\text { Oxaliplatin }\end{array}$ & 36 & 12 steps, 1 dilution & 4.2 & Inpatient non-ICU & Yes & 16.7 & 100 \\
\hline \begin{tabular}{|c|} 
Confino-Cohen \\
et al. $[19]$
\end{tabular} & Carboplatin & 23 & $\begin{array}{c}4 \text { step, } 4 \text { dilution from } \\
1: 1000 \text { to } 1: 1 \\
\end{array}$ & 6 & N/A & Yes & 5 & 95 \\
\hline \begin{tabular}{|c|} 
Cortijo- \\
Cascajares et al. \\
{$[20]$} \\
\end{tabular} & Oxaliplatin & 21 & $\begin{array}{l}14 \text { step, } 13 \text { dilutions } \\
\text { from } 1: 100 \text { to } 1: 1\end{array}$ & $3-4$ & N/A & Yes & 11 & 100 \\
\hline \begin{tabular}{|c|} 
Gastaminza $e t$ \\
$a l .[23]$ \\
\end{tabular} & $\begin{array}{l}\text { Carboplatin } \\
\text { Oxaliplatin }\end{array}$ & 4 & $\begin{array}{l}5 \text { step, } 5 \text { dilutions } \\
\text { from } 1: 10000 \text { to } 1: 1\end{array}$ & 2 & $\begin{array}{c}\text { Inpatient non-ICU } \\
\text { ICU } 1^{\text {st }} \text { administration } \\
\end{array}$ & Yes & 25 & 75 \\
\hline $\begin{array}{c}\text { Gomez et al. } \\
{[25]}\end{array}$ & Carboplatin & 7 & $\begin{array}{l}4 \text { steps, } 4 \text { dilutions } \\
\text { from } 1: 1000 \text { to } 1: 1\end{array}$ & 2 & N/A & Yes & 28.5 & 85.7 \\
\hline Jones et al. [29] & $\begin{array}{c}\text { Carboplatin } \\
\text { Cisplatin }\end{array}$ & 5 & $\begin{array}{l}4 \text { steps, } 4 \text { dilutions } \\
\text { from } 1: 1000 \text { to } 1: 1\end{array}$ & 1.5 & Inpatient non-ICU & Yes & 40 & 60 \\
\hline Kang et al. [30] & $\begin{array}{l}\text { Carboplatin } \\
\text { Oxaliplatin } \\
\text { Cisplatin }\end{array}$ & 36 & $\begin{array}{c}12 \text { step, } 3 \text { dilutions } \\
\text { from } 1: 100-1: 1 \\
16 \text { step, } 4 \text { dilutions } \\
1: 1000-1: 1 \\
\end{array}$ & 7.8 & Inpatient non-ICU & Yes & 44.8 & 91.6 \\
\hline Kendirlinan $e t$ & $\begin{array}{l}\text { Carboplatin } \\
\text { Oxaliplatin }\end{array}$ & 22 & $\begin{array}{l}12 \text { step, } 3 \text { dilutions } \\
\text { from 1:100-1:1 }\end{array}$ & N/A & Inpatient non-ICU & Yes & 50 & 90.9 \\
\hline$a l .[31]$ & Cisplatin & & $\begin{array}{c}16 \text { step, } 4 \text { dilutions } \\
1: 1000-1: 1\end{array}$ & N/A & & & & \\
\hline Lee et al. [37] & Carboplatin & 31 & $\begin{array}{l}12 \text { step, } 3 \text { dilutions } \\
\text { from } 1: 100-1: 1\end{array}$ & 3.8 & $\begin{array}{c}\text { Inpatient non-ICU } \\
\text { ICU } 1^{\text {st }} \text { administration } \\
\end{array}$ & Yes & 30.5 & 100 \\
\hline Lee et al. [36] & Carboplatin & 10 & $\begin{array}{l}12 \text { step, } 3 \text { dilutions } \\
\text { from } 1: 100-1: 1\end{array}$ & 5.82 & $\begin{array}{c}\text { Inpatient non-ICU } \\
\text { ICU } 1^{\text {st }} \text { administration }\end{array}$ & Yes & 40 & 100 \\
\hline
\end{tabular}


FARMACIA, 2021, Vol. 69, 3

\begin{tabular}{|c|c|c|c|c|c|c|c|c|}
\hline & Chemotherapy & Patients & Protocol & \begin{tabular}{|c|}
$\begin{array}{c}\text { Duration } \\
\text { (hours) }\end{array}$ \\
\end{tabular} & Setting & \begin{tabular}{|c|} 
Skin \\
testing
\end{tabular} & \begin{tabular}{|c|} 
BTR \\
$(\%)$
\end{tabular} & $\begin{array}{l}\text { Success } \\
\text { rate }(\%)\end{array}$ \\
\hline Li et al. [39] & $\begin{array}{l}\text { Carboplatin } \\
\text { Cisplatin }\end{array}$ & 18 & 4 step, 1 dilution & $1.5-2.25$ & Outpatient & No & 32 & 100 \\
\hline $\begin{array}{c}\text { Madrigal- } \\
\text { Burgaleta } \text { et al. } \\
{[41]} \\
\end{array}$ & $\begin{array}{l}\text { Oxaliplatin } \\
\text { Carboplatin }\end{array}$ & 11 & 10 steps, 3 dilutions & 4.25 & ICU & Yes & 6 & 100 \\
\hline $\begin{array}{c}\text { Madrigal- } \\
\text { Burgaleta } \text { et al. } \\
{[42]} \\
\end{array}$ & $\begin{array}{c}\text { Carboplatin } \\
\text { Oxaliplatin } \\
\text { Cisplatin } \\
\end{array}$ & 104 & 10 steps, 3 dilutions & 4.5 & $\begin{array}{c}\text { Inpatient non-ICU } \\
\text { ICU } 1^{\text {st }} \text { administration }\end{array}$ & Yes & 12 & 100 \\
\hline $\begin{array}{c}\text { Markman et al. } \\
\text { [47] }\end{array}$ & $\begin{array}{c}\text { Carboplatin } \\
\text { Cisplatin }\end{array}$ & 4 & $\begin{array}{l}4 \text { steps, } 4 \text { dilutions } \\
\text { from } 1: 1000 \text { to } 1: 1\end{array}$ & 1.5 & N/A & Yes & 0 & 100 \\
\hline Park et al. [59] & $\begin{array}{l}\text { Oxaliplatin } \\
\text { Cisplatin }\end{array}$ & 12 & $\begin{array}{l}11 \text { step, } 4 \text { dilution } \\
\text { from } 1: 1000 \text { to } 1: 1\end{array}$ & 6.38 & N/A & Yes & 42.8 & 100 \\
\hline $\begin{array}{c}\text { Pérez-Rodríguez } \\
\text { et al. }[61]\end{array}$ & $\begin{array}{c}\text { Oxaliplatin } \\
\text { Carboplatin }\end{array}$ & 46 & 9 steps, 1 dilution & 3.48 & Outpatient & Yes & 5.3 & 95.6 \\
\hline $\begin{array}{c}\text { Robinson et al. } \\
{[64]}\end{array}$ & $\begin{array}{c}\text { Carboplatin } \\
\text { Cisplatin } \\
\end{array}$ & 10 & $\begin{array}{l}4 \text { steps, } 4 \text { dilutions } \\
\text { from } 1: 1000 \text { to } 1: 1\end{array}$ & 4 & N/A & Yes & 0 & 100 \\
\hline Rose et al. [65] & Carboplatin & 33 & $\begin{array}{l}4 \text { steps, } 4 \text { dilutions } \\
\text { from } 1: 1000 \text { to } 1: 1\end{array}$ & 16.5 & Inpatient non-ICU & No & 22 & 78 \\
\hline $\begin{array}{c}\text { Syrigou et al. } \\
{[73]}\end{array}$ & Oxaliplatin & 3 & \begin{tabular}{|c|}
13 steps, 7 dilutions \\
from $1: 100000$ to $1: 1$
\end{tabular} & 8 & Outpatient & Yes & 0 & 100 \\
\hline $\begin{array}{c}\text { Takase } \text { et al. } \\
{[74]}\end{array}$ & Carboplatin & 20 & $\begin{array}{l}4 \text { steps, } 4 \text { dilutions } \\
\text { from } 1: 1000 \text { to } 1: 1\end{array}$ & 4 & Inpatient non-ICU & No & 15 & 95 \\
\hline $\begin{array}{c}\text { Toyohara et al. } \\
{[75]}\end{array}$ & Carboplatin & 5 & $\begin{array}{l}4 \text { steps, } 4 \text { dilutions } \\
\text { from } 1: 1000 \text { to } 1: 1\end{array}$ & 5 & Inpatient non-ICU & No & 20 & 80 \\
\hline \multirow[b]{2}{*}{ Vetter et al. [77] } & \multirow{2}{*}{$\begin{array}{c}\text { Carboplatin } \\
\text { Cisplatin }\end{array}$} & \multirow[t]{2}{*}{48} & 4 steps, 1 dilution & 2.25 & Outpatient & \multirow[t]{2}{*}{ No } & \multirow[t]{2}{*}{65} & \multirow[t]{2}{*}{96.6} \\
\hline & & & $\begin{array}{l}16 \text { steps, } 3 \text { dilutions } \\
\text { from } 1: 100 \text { to } 1: 1\end{array}$ & 14 & Inpatient & & & \\
\hline Vidal et al. [78] & Carboplatin & 8 & 16 steps, 1 dilution & 4.5 & Outpatient & Yes & 12.5 & 100 \\
\hline Wong et al. [80] & Oxaliplatin & 48 & $\begin{array}{c}13 \text { steps, } 3 \text { dilutions } \\
\text { from } 1: 1000000 \text { to } 1: 10\end{array}$ & $4.7-16$ & N/A & Yes & 37.5 & 100 \\
\hline
\end{tabular}

BTR: breakthrough reactions, ICU: intensive care unit, N/A: not available

A recent study by Castells et al. [15] used a standardized 12-step desensitization protocol in 98 patients; among these, 64 had platinum-related allergic reactions. Subjects received premedication followed by the administration of three solutions in twelve consecutive steps. Total desensitization time was of 5.8 hours. The first desensitization was administered in an intensive care unit while the others were administered in an outpatient setting. Of the 413 desensitizations performed, $94 \%$ lead to no or mild reactions. Most reactions occurred during the first two desensitisations, more frequently during the final step of the protocol; however, all reactions were less severe than the initial allergic reaction. In patients presenting with HSR related symptoms, despite desensitization, the addition of $325 \mathrm{mg}$ of acetylsalicylic acid and $10 \mathrm{mg}$ of montelukast two days prior and on the desensitization day led to significant symptom control [6].

Altwerger et al. conducted an analysis encompassing 129 patients who received a total of 788 desensitization cycles for carboplatin. A four-step desensitization protocol was used, and total administration time was of 3.5 hours. Two patient groups underwent desensitization, patients with prior HSR to carboplatin $(43.4 \%)$ and patients with positive carboplatin skin tests. Patients with positive skin tests presented more HSR during desensitization than those with a history of HSR. Most patients received their desensitization in a nonintensive care inpatient unit, $87.6 \%$ completed their desensitization, with an average of 6.1 desensitization cycles administered. Most patients had no or mild reactions during desensitization, $9 \%$ presented moderate to life-threatening events, and one death occurred due to a severe anaphylactic reaction [2].

In patients with a history of platinum induced allergic reactions, skin testing was advocated as a useful tool in predicting future reactions and selecting patients for further platinum reexposure. However, the use of skin testing in an everyday clinical setting remains controversial as the sensitivity of skin tests for platinum salts varies across different studies, from $66 \%$ to 80 $88 \%$, in some studies as low as $27 \%$ for oxaliplatin [9] and multiple tests are frequently necessary for adequate risk stratification. Hesterberg et al. used skin testing for selecting the desensitization protocol in patients with carboplatin HSR. Patients with negative skin tests received a more rapid 8 step protocol, while those with positive tests had a longer 10 step desensitization protocol. Subjects with negative skin tests within three months of the HSR did not display hypersensitivity symptoms during desensitization and 
remained negative. Patients with testing performed at more than 9 months after HSR tested positive before the second desensitization cycle and had subsequent reactions even during the prolonged desensitization protocol [26].

Skin testing, however, may be effective in selecting patients with a very low risk for further allergic reactions. A three-step risk stratification protocol was analysed in a retrospective analysis conducted by Wang et al. in 142 patients with carboplatin and oxaliplatin HSR. Patients with negative tests undergone 8-step desensitization regimen with repeated skin testing before each cycle. Patients that remained negative after the third test continued their treatment schedule without desensitization. $77.3 \%$ for carboplatin and $88.9 \%$ for oxaliplatin, of the patients that continued outpatient treatment without desensitization, had no additional HSR related symptoms. However, patients with severe initial HSR, even though they qualified for treatment without desensitization, were not referred to outpatient infusions [79]. Caiado et al. searched for potential biomarkers that may aid in selecting patients at risk for allergic reactions during desensitization by analysing 1471 desensitizations in 272 patients. On multivariate analysis, a total Ig E level greater than $100 \mathrm{U} / \mathrm{mL}$ and more than ten previous platinum administration were found as significant risk factors for further HSR during desensitizations with an OR of 8.24 and 4.11, respectively [8].

\section{Conclusions}

Platinum derivates are essential chemotherapeutic agents, and they represent the treatment mainstay in a variety of cancers. However, hypersensitivity reactions greatly impair the administration of platinum agents, especially in patients with a history of atopy, a large platinum-free interval and patients with more than seven administrations. Continuation of platinumbased chemotherapy after an initial allergic reaction is highly unsafe as hypersensitivity reactions are potentially fatal complications. Also, due to crossreactivity, switching platinum compounds may not be the preferred option. Therefore, in patients with limited alternative treatment options or patients with cancers where platinum chemotherapy is essential, desensitization protocols are viable options. Various protocols have been published, and they allow treatment completion with a good safety and efficacy profile. Desensitisations should be administered in a specialized ward with personnel trained in desensitization administration and management of severe hypersensitivity and anaphylaxis as there remains a risk for potentially life-threatening allergic reactions. Further research is needed in selecting patients suitable for desensitisation, identifying those who are at risk and should receive desensitisation before an allergic reaction and optimising desensitisation protocols.

\section{Acknowledgement}

This research was funded by a grant of Romanian Ministry of Research and Innovation, Project number POC - P_40_318 - Knowledge transfer of biogenomics in oncology and related domains in clinical applications BIOGENONCO, MySMIS Code: 105774, Financing contract No: 10/01.09.2016.

\section{Conflict of interest}

The authors declare no conflict of interest.

\section{References}

1. Abe A, Ikawa H, Ikawa S, Desensitization treatment with cisplatin after carboplatin hypersensitivity reaction in gynecologic cancer. J Med Investig., 2010; 57(1,2): 163-167.

2. Altwerger G, Gressel GM, English DP, Nelson WK, Carusillo N, Silasi DA, Azodi M, Santin A, Schwartz PE, Ratner ES, Platinum desensitization in patients with carboplatin hypersensitivity: A single-institution retrospective study. Gynecol Oncol., 2017; 144(1): 77-82.

3. Arbour KC, Riely GJ, Systemic Therapy for Locally Advanced and Metastatic Non-Small Cell Lung Cancer. JAMA, 2019; 322(8): 764-774.

4. Bano N, Najam R, Qazi F, Mateen A, Clinical Features of Oxaliplatin Induced Hypersensitivity Reactions and Therapeutic Approaches. Asian Pacific J Cancer Prev., 2016; 17(4): 1637-1641.

5. Brault F, Waton J, Poreaux C, Schmutz JL, Barbaud A, Hypersensibilité aux sels de platine et aux taxanes: intérêt des tests cutanés et des inductions de tolérance. Ann Dermatol Venereol., 2017; 144(11): 685-695.

6. Breslow RG, Caiado J, Castells MC, Acetylsalicylic acid and montelukast block mast cell mediator-related symptoms during rapid desensitization. Ann Allergy Asthma Immunol., 2009; 102(2): 155-160.

7. Bruchim I, Goldberg A, Fishman A, Confino-Cohen $\mathrm{R}$, Carboplatin hypersensitivity: evaluation and successful desensitization protocol. Immunotherapy, 2014; 6(8): 905-912.

8. Caiado J, Brás R, Paulino M, Costa L, Castells M, Rapid desensitization to antineoplastic drugs in an outpatient immunoallergology clinic: Outcomes and risk factors. Ann Allergy Asthma Immunol., 2020; 125(3): 325-333.e1.

9. Caiado J, Castells M, Presentation and Diagnosis of Hypersensitivity to Platinum Drugs. Curr Allergy Asthma Rep., 2015; 15(4): 1-9.

10. Cainap C, Vlad C, Seicean A, Balacescu O, Seicean R, Constantin AM, Balacescu L, Crisan O, Marta MM, Cainap S, Gastric cancer: adjuvant chemotherapy versus chemoradiation. A clinical point of view. $J$ BUON, 2019; 24(6): 2209-2219.

11. Cancer Institute $\mathrm{N}$, Common Terminology Criteria for Adverse Events (CTCAE) Version 4.0 [Internet], 2009.

12. Capdevila J, Elez E, Peralta S, Macarulla T, Ramos FJ, Tabernero J, Oxaliplatin-based chemotherapy in the management of colorectal cancer. Expert Rev Anticancer Ther., 2008; 8(8): 1223-1236. 
FARMACIA, 2021, Vol. 69, 3

13. Castells M, Drug Hypersensitivity and Anaphylaxis in Cancer and Chronic Inflammatory Diseases: The Role of Desensitizations. Front Immunol., 2017; 8: 1-11.

14. Castells M, Rapid desensitization for hypersensitivity reactions to chemotherapy agents. CurrOpin Allergy Clin Immunol., 2006; 6(4): 271-277.

15. Castells MC, Tennant NM, Sloane DE, Hsu FI, Barrett NA, Hong DI, Laidlaw TM, Legere HJ, Nallamshetty SN, Palis RI, Rao JJ, Berlin ST, Campos SM, Matulonis UA, Hypersensitivity reactions to chemotherapy: Outcomes and safety of rapid desensitization in 413 cases. J Allergy Clin Immunol., 2008; 122(3): 574-580.

16. Cetean S, Ciuleanu T, Leucuta DC, Cainap C, Constantin AM, Cazacu I, Cainap S, Gherman A, Oprean L, Hangan A, Oprean R, Hypersensitivity reactions to platinum derivatives: findings of new predictive markers. J BUON, 2015; 20(6): 1617-1623.

17. Choi J, Harnett P, Fulcher DA, Carboplatin desensitization. Ann Allergy Asthma Immunol., 2004; 93(2): 137-141.

18. Chung SJ, Kang SY, Kang RY, Kim YC, Lee KH, Kim TY, Han SW, Kang HR, A new non-dilution rapid desensitization protocol successfully applied to all-grade platinum hypersensitivity. Cancer Chemother Pharmacol., 2018; 82(5): 777-785.

19. Confino-Cohen R, Fishman A, Altaras M, Goldberg A, Successful carboplatin desensitization in patients with proven carboplatin allergy. Cancer, 2005; 104(3): 640-643.

20. Cortijo-Cascajares S, Nacle-López I, García-Escobar I, Aguilella-Vizcaíno MJ, Herreros-de-Tejada A, Cortés-Funes Castro H, Calleja-Hernández MÁ, Effectiveness of oxaliplatin desensitization protocols. Clin Transl Oncol., 2013; 15(3): 219-225.

21. Curtis BR, Kaliszewski J, Marques MB, Saif MW, Nabelle L, Blank J, McFarland JG, Aster RH, Immune-mediated thrombocytopenia resulting from sensitivity to oxaliplatin. Am J Hematol., 2006; 81(3): 199-201.

22. Gaeta TJ, Clark S, Pelletier AJ, Camargo CA, National study of US emergency department visits for acute allergic reactions, 1993 to 2004. Ann Allergy Asthma Immunol., 2007; 98(4): 360-365.

23. Gastaminza G, de la Borbolla JM, Goikoetxea MJ, Escudero R, Antón J, Espinós J, Lacasa C, FernándezBenítez M, Sanz ML, Ferrer M, A new rapid desensitization protocol for chemotherapy agents. $J$ Investig Allergol Clin Immunol., 2011; 21(2): 108-112.

24. Giavina-Bianchi P, Patil SU, Banerji A, Immediate Hypersensitivity Reaction to Chemotherapeutic Agents. J Allergy Clin Immunol Pract., 2017; 5(3): 593-599.

25. Gomez R, Harter P, Lück HJ, Traut A, Kommoss S, Kandel M, du Bois A, Carboplatin hypersensitivity does introduction of skin test and desensitization reliably predict and avoid the problem? A prospective single-center study. Int J Gynecol Cancer., 2009; 19(7): 1284-1287.

26. Hesterberg PE, Banerji A, Oren E, Penson RT, Krasner CN, Seiden MV, Wong JT, Risk stratification for desensitization of patients with carboplatin hypersensitivity: Clinical presentation and management. J Allergy Clin Immunol., 2009; 123(6): 1262-1267.e1.
27. Jerschow E, Lin RY, Scaperotti MM, McGinn AP, Fatal anaphylaxis in the United States, 1999-2010: temporal patterns and demographic associations. $J$ Allergy Clin Immunol., 2014; 134(6): 1318-1328.e7.

28. Joly F, Ray-Coquard I, Fabbro M, Donoghoe M, Boman K, Sugimoto A, Vaughan M, Reinthaller A, Vergote I, Ferrandina G, Dell'Anna T, Huober J, Pujade-Lauraine E, Decreased hypersensitivity reactions with carboplatin-pegylated liposomal doxorubicin compared to carboplatin-paclitaxel combination: Analysis from the GCIG CALYPSO relapsing ovarian cancer trial. Gynecol Oncol., 2011; 122(2): 226-232.

29. Jones R, Ryan M, Friedlander M, Carboplatin hypersensitivity reactions: re-treatment with cisplatin desensitisation. Gynecol Oncol., 2003; 89(1): 112-115.

30. Kang Y, Kwon OY, Jung H, Kang M, An J, Lee JH, Won HK, Song WJ, Kwon HS, Cho YS, Moon HB, Kim TB. Breakthrough reactions during rapid drug desensitization: Clinical outcome and risk factors, Breakthrough reactions during rapid drug desensitization: Clinical outcome and risk factors. Ann Allergy Asthma Immunol., 2019; 123(1): 48-56.e1.

31. Kendirlinan R, Gümüşburun R, Çerçi $P$, Özbek E, Altıner S, ÇelebiSözener Z, Soyyiğit Ş, Aydın Ö, Rapid Drug Desensitization with Chemotherapeutics (Platins, Taxanes, and Others): A Single-Center Retrospective Study. Int Arch Allergy Immunol., 2019; 179(2): 114-122.

32. Kim BH, Bradley T, Tai J, Budman DR, Hypersensitivity to Oxaliplatin: An Investigation of Incidence and Risk Factors, and Literature Review. Oncology, 2009; 76(4): 231-238.

33. Koren C, Yerushalmi R, Katz A, Malik H, Sulkes A, Fenig E, Hypersensitivity reaction to cisplatin during chemoradiation therapy for gynecologic malignancy. Am J Clin Oncol., 2002; 25(6): 625-626.

34. Kuo JC, Hawkins C, Yip D, Treatment outcomes of rapid desensitisation protocols for chemotherapeutic agents and monoclonal antibodies following hypersensitivity reactions. Intern Med J., 2014; 44(5): 442-449.

35. LaVigne K, Hyman DM, Zhou QC, Iasonos A, Tew WP, Aghajanian C, Makker V, Hensley ML, Konner J, Grisham RN, Cangemi N, Soldan K, Spriggs DR, Sabbatini PJ, O'Cearbhaill RE, A Randomized Trial of Prophylactic Extended Carboplatin Infusion to Reduce Hypersensitivity Reactions in Recurrent Ovarian Cancer. Int J Gynecol Cancer., 2018; 28(6): 1176-1182.

36. Lee C-W, Matulonis UA, Castells MC, Carboplatin hypersensitivity: a 6-h 12-step protocol effective in 35 desensitizations in patients with gynecological malignancies and mast cell//gE-mediated reactions. Gynecol Oncol., 2004; 95(2): 370-376.

37. Lee CW, Matulonis UA, Castells MC, Rapid inpatient/outpatient desensitization for chemotherapy hypersensitivity: Standard protocol effective in 57 patients for 255 courses. Gynecol Oncol., 2005; 99(2): 393-399.

38. Leonard GD, Wright MA, Quinn MG, Fioravanti S, Harold N, Schuler B, Thomas RR, Grem JL. Survey of oxaliplatin-associated neurotoxicity using an interviewbased questionnaire in patients with metastatic colorectal cancer. BMC Cancer, 2005; 5: 1-10. 
39. Li Q, Cohn D, Waller A, Backes F, Copeland L, Fowler J, Salani R, O'Malley D. Outpatient rapid 4step desensitization for gynecologic oncology patients with mild to low-risk, moderate hypersensitivity reactions to carboplatin/cisplatin. Gynecol Oncol., 2014; 135(1): 90-94.

40. Limsuwan T, Castells MC, Outcomes and safety of rapid desensitization for chemotherapy hypersensitivity. Expert Opin Drug Saf., 2010; 9(1): 39-53.

41. Madrigal-Burgaleta R, Berges-Gimeno MP, AngelPereira D, Ferreiro-Monteagudo R, Guillen-Ponce C, Pueyo C, Gomez de Salazar E, Alvarez-Cuesta E, Hypersensitivity and desensitization to antineoplastic agents: outcomes of 189 procedures with a new short protocol and novel diagnostic tools assessment. Allergy, 2013; 68(7): 853-861.

42. Madrigal-Burgaleta R, Bernal-Rubio L, BergesGimeno MP, Carpio-Escalona LV, Gehlhaar P, Alvarez-Cuesta E, A Large Single-Hospital Experience Using Drug Provocation Testing and Rapid Drug Desensitization in Hypersensitivity to Antineoplastic and Biological Agents. J Allergy Clin Immunol Pract., 2019; 7(2): 618-632.

43. Maindrault-Goebel F, André T, Tournigand C, Louvet C, Perez-Staub N, Zeghib N, De Gramont A. Allergic-type reactions to oxaliplatin: retrospective analysis of 42 patients. Eur J Cancer., 2005; 41(15) :2262-2267.

44. Makrilia N, Syrigou E, Kaklamanos I, Manolopoulos L, Saif MW, Hypersensitivity Reactions Associated with Platinum Antineoplastic Agents: A Systematic Review. Met Based Drugs., 2010; 2010: 1-11.

45. Markman M, Kennedy A, Webster K, Elson P, Peterson G, Kulp B, Belinson J. Clinical features of hypersensitivity reactions to carboplatin. J Clin Oncol., 1999; 17(4): 1141-1145.

46. Markman M, Zanotti K, Kulp B, Peterson G, Markman M, Relationship between a history of systemic allergic reactions and risk of subsequent carboplatin hypersensitivity. Gynecol Oncol., 2003; 89(3): 514516.

47. Markman M, Hsieh F, Zanotti K, Webster K, Peterson G, Kulp B, Spicel A, Belinson J, Initial experience with a novel desensitization strategy for carboplatin-associated hypersensitivity reactions: Carboplatin-hypersensitivity reactions. J Cancer Res Clin Oncol., 2004; 130(1): 25-28.

48. Matei D, Filiaci V, Randall ME, Mutch D, Steinhoff MM, DiSilvestro PA, Moxley KM, Kim YM, Powell MA, O'Malley DM, Spirtos NM, Small W Jr, Tewari KS, Richards WE, Nakayama J, Matulonis UA, Huang HQ, Miller DS, Adjuvant chemotherapy plus radiation for locally advanced endometrial cancer. N Engl J Med., 2019; 380(24): 2317-2326.

49. Matulonis UA, Sood AK, Fallowfield L, Howitt BE, Sehouli J, Karlan BY, Ovarian cancer. Nat Rev Dis Prim., 2016; 2(1): 16061: 1-48.

50. van Meerbeeck JP, Fennell DA, De Ruysscher DKM, Small-cell lung cancer. Lancet, 2011; 378(9804): 1741-155.

51. Miyamoto S, Okada R, Ando K, Platinum hypersensitivity and desensitization. Jpn J Clin Oncol., 2015; 45(9): 795-804.
52. Moon DH, Lee JM, Noonan AM, Annunziata CM, Minasian L, Houston N, Hays JL, Kohn EC, Deleterious BRCA1/2 mutation is an independent risk factor for carboplatin hypersensitivity reactions. Br J Cancer, 2013; 109(4): 1072-1078.

53. Morgan JS, Adams M, Mason MD, Hypersensitivity reactions to carboplatin given to patients with relapsed ovarian carcinoma. Eur J Cancer, 1994; 30A(8): 1205-1206.

54. Movva S, Rodriguez L, Arias-Pulido H, Verschraegen C, Novel chemotherapy approaches for cervical cancer. Cancer, 2009; 115(14): 3166-3180.

55. Navo M, Kunthur A, Badell ML, Coffer LW 2nd, Markman M, Brown J, Smith JA, Evaluation of the incidence of carboplatin hypersensitivity reactions in cancer patients. Gynecol Oncol., 2006; 103(2): 608-613.

56. O'Cearbhaill R, Zhou Q, Iasonos A, Hensley ML, Tew WP, Aghajanian C, Spriggs DR, Lichtman SM, Sabbatini PJ, The prophylactic conversion to an extended infusion schedule and use of premedication to prevent hypersensitivity reactions in ovarian cancer patients during carboplatin retreatment. Gynecol Oncol., 2010; 116(3): 326-331.

57. O'Malley DM, Vetter MH, Cohn DE, Khan A, Hays JL, Outpatient desensitization in selected patients with platinum hypersensitivity reactions. Gynecol Oncol., 2017; 145(3): 603-610.

58. Otani IM, Wong J, Banerji A, Platinum Chemotherapy Hypersensitivity. Immunol Allergy Clin North Am., 2017; 37(4): 663-677.

59. Park HJ, Lee JH, Kim SR, Kim SH, Park KH, Lee CK, Kang BD, Beom SH, Shin SJ, Jung M, Park JW, A new practical desensitization protocol for oxaliplatin-induced immediate hypersensitivity reactions: A necessary and useful approach. J InvestigAllergol Clin Immunol., 2016; 26(3): 168-176.

60. Pasternak AL, Link NA, Richardson CM, Rose PG, Effect of Prophylactic Extended-Infusion Carboplatin on Incidence of Hypersensitivity Reactions in Patients with Ovarian, Fallopian Tube, or Peritoneal Carcinomas. Pharmacotherapy, 2016; 36(7): 723-730.

61. Pérez-Rodríguez E, Martínez-Tadeo JA, PérezRodríguez N, Hernández-Santana G, Callero-Viera A, Rodríguez-Plata E, García-Robaina JC, Outcome of 490 Desensitizations to Chemotherapy Drugs with a Rapid One-Solution Protocol. J Allergy Clin Immunol Pract., 2018; 6(5): 1621-1627.e6.

62. Polyzos A, Tsavaris N, Gogas H, Souglakos J, Vambakas L, Vardakas N, Polyzos K, Tsigris C, Mantas D, Papachristodoulou A, Nikiteas N, Karavokyros JG, Felekouras E, Griniatsos J, Giannopoulos A, Kouraklis $\mathrm{G}$, Clinical features of hypersensitivity reactions to oxaliplatin: A 10-year experience. Oncology, 2008; 76(1): 36-41

63. Popescu FD, Cristea OM, Ionica FE, Vieru M, Drug allergies due to IgE sensitization to $\alpha$-GAL. Farmacia, 2019; 67(1): 43-49.

64. Robinson JB, Singh D, Bodurka-Bevers DC, Wharton JT, Gershenson DM, Wolf JK, Hypersensitivity Reactions and the Utility of Oral and Intravenous Desensitization in Patients with Gynecologic Malignancies. Gynecol Oncol., 2001; 82(3): 550-558. 
65. Rose PG, Fusco N, Smrekar M, Mossbruger K, Rodriguez M, Successful administration of carboplatin in patients with clinically documented carboplatin hypersensitivity. Gynecol Oncol., 2003; 89(3): 429433.

66. Roselló S, Blasco I, GarćaFabregat L, Cervantes A, Jordan K, Management of infusion reactions to systemic anticancer therapy: ESMO Clinical Practice Guidelines. Ann Oncol., 2017; 28(Supplement 4): iv100-118.

67. Ruggiero A, Trombatore G, Triarico S, Arena R, Ferrara P, Scalzone M, Pierri F, Riccardi R, Platinum compounds in children with cancer: Toxicity and clinical management. Anticancer Drugs., 2013; 24(10): 1007-1019.

68. Sancho-Serra M del C, Simarro M, Castells M, Rapid IgE desensitization is antigen specific and impairs early and late mast cell responses targeting FceRI internalization. Eur J Immunol., 2011; 41(4): 10041013.

69. Scheau C, Mihai LG, Badarau IA, Caruntu C, Emerging applications of some important natural compounds in the field of oncology. Farmacia, 2020; 68(6): 984- 991.

70. Siu SWK, Chan RTT, Au GKH, Hypersensitivity reactions to oxaliplatin: Experience in a single institute. Ann Oncol., 2006; 17(2): 259-261.

71. Sliesoraitis S, Chikhale PJ, Carboplatin hypersensitivity. Int J Gynecol Cancer., 2005; 15(1): 13-18.

72. Sullivan TJ, Antigen-specific desensitization of patients allergic to penicillin. J Allergy Clin Immunol., 1982; 69(6): 500-508.

73. Syrigou EI, Karapanagiotou EM, Alamara CV, Boura PG, Saif MW, Syrigos KN, Hypersensitivity reactions to oxaliplatin: A retrospective study and the development of a desensitization protocol. Clin Colorectal Cancer., 2009; 8(2): 106-109.

74. Takase N, Matsumoto K, Onoe T, Kitao A, Tanioka M, Kikukawa Y, Yamaguchi S, Fujiwara K, Negoro S, 4-Step 4-H Carboplatin Desensitization Protocol for
Patients With Gynecological Malignancies Showing Platinum Hypersensitivity: a Retrospective Study. Int J Clin Oncol., 2015; 20(3): 566-573.

75. Toyohara Y, Sone K, Nishida H, Taguchi A, Miyamoto Y, Tanikawa M, Mori M, Tsuruga T, Matsumoto Y, Oda K, Osuga Y, Fujii T, Desensitization strategy for hypersensitivity reactions to carboplatin in five patients with gynecological cancer. J Obstet Gynaecol Res., 2020; 46(11): 2298-2304.

76. Uzzaman A, Cho SH, Chapter 28: Classification of hypersensitivity reactions. Allergy Asthma Proc., 2012; 33(3): 96-99.

77. Vetter MH, Khan A, Backes FJ, Bixel K, Cohn DE, Copeland LJ, Fowler JM, Salani R, Li Q, O'Malley DM, Outpatient desensitization of patients with moderate (high-risk) to severe platinum hypersensitivity reactions. Gynecol Oncol., 2019; 152(2): 316-321.

78. Vidal C, Méndez-Brea P, López-Freire S, Bernárdez B, Lamas MJ, Armisén M, Rodríguez V, Luna I, Castro-Murga M, A modified protocol for rapid desensitization to chemotherapy agents. J Allergy Clin Immunol Pract., 2016; 4(5): 1003-1005.

79. Wang AL, Patil SU, Long AA, Banerji A, Riskstratification protocol for carboplatin and oxaliplatin hypersensitivity: repeat skin testing to identify drug allergy. Ann Allergy Asthma Immunol., 2015; 115(5): 422-428.

80. Wong JT, Ling M, Patil S, Banerji A, Long A, Oxaliplatin Hypersensitivity: Evaluation, Implications of Skin Testing, and Desensitization. J Allergy Clin Immunol Pract., 2014; 2(1): 40-45.

81. Yu DY, Dahl GVH, Shames RS, Fisher PG, Weekly dosing of carboplatin increases risk of allergy in children. Am J Pediatr Hematol Oncol., 2001; 23(6): 349-352.

82. Zanotti KM, Markman M, Prevention and Management of Hypersensitivity Reactions. Drug Saf., 2001; 24(10): 767-779. 